\title{
Nutritional Support for Critically Ill Adult Patients for Developing Countries
}

\author{
Demeke Yilka'* and Basazinew Cheko ${ }^{1}$ \\ Department of Anesthesia and Critical care, University of Gondar Specialized Hospital, Ethiopia
}

Submission: August 02, 2019; Published: August 26, 2019

*Corresponding author: Demeke Yilkal, College of Medicine and Health Science, Department of Anesthesia and Critical care, University of Gondar specialized hospital, Gondar, Ethiopia

\begin{abstract}
Objective: This review was conducted to develop evidence-based clinical practice guidelines for nutrition support in critically ill adult patients admitted in intensive care unit.

Options: The following interventions were systematically reviewed for inclusion in the guidelines. Enteral nutrition (EN) versus parenteral nutrition (PN), early versus late enteral nutrition, composition of EN (protein, carbohydrates, lipids, locally available foods), strategies to optimize delivery of enteral nutrition and minimize risks, enteral nutrition in combination with supplemental PN, use of PN versus standard care in patients with an intact gastrointestinal tract, dose of PN and composition of PN (protein, carbohydrates, IV lipids, additives, vitamins, trace elements).
\end{abstract}

Evidence: We systematically searched hinari/PubMed/PMC, Google scholar, the Cochrane Library for randomized controlled trials and meta-analyses of randomized controlled trials that evaluated any form of nutrition support in critically ill adults. We also searched reference lists and personal files, considering all articles published or unpublished available by April 2017. Each included study was critically appraised.

Summary of evidence and recommendation: When considering nutrition support in critically ill patients, we strongly recommend that enteral nutrition is preferred to PN. We recommend the use of a standard, polymeric enteral formula that is initiated within 24 to 48 hours after admission to ICU, that patients be cared for in the semi recumbent position

Keywords: Adult; Critical illness; Intensive care unit

\section{Introduction}

The significance of nutrition in the hospital setting cannot be overstated. This significance is particularly noted in the ICU. Critical illness is typically associated with a catabolic stress state in which patients commonly demonstrate a systemic inflammatory response. FAST HUG is a mnemonic used in the intensive care unit (ICU) to aide healthcare professionals in preparation for patient rounds, help to identify and prevent medication errors, promote patient safety, and maximize therapeutic interventions. And from this feeding is the one that we should consider during management. Therefore, critically ill patients need strict follow up for their nutrition support. Artificial nutrition support has evolved into a primary therapeutic intervention to prevent metabolic deterioration, loss of lean body mass and aim to improve the outcome of critically ill patients.

According to the specialized literature which is critical review and algorithm creation, the prevalence of under nutrition among hospitalized individual ranges from $18.2 \%$ to $40 \%$ due to critically ill patients in ICU are in high metabolic state with an increased demand for energy \& protein due to stress, trauma, infection and other reasons. They have eating and gastric motility disorders and inefficient nutrient uptake which leads them to malnutrition $[1,2]$. Artificial nutrition support has evolved into a primary therapeutic intervention to prevent metabolic deterioration and loss of lean body mass, aim to improve the outcome of critically ill patients [3].

Nutritional support is standard for critically ill patients and requires a complex calculus of timing, route of delivery, and the amount and type of nutrients that are administered [4].

Enteral nutrition delivery is the preferred optimal method of nutritional supplement in patients in the ICU. After careful consideration of an individual patient's illness severity, level of physiologic stress, and baseline nutritional status, early enteral feeding has been shown to attenuate disease severity, maintain gastrointestinal (GI) physiology, and modulate the immune system [5].

Nutritional support is needed to overcome stress-induced metabolic responses, prevent oxidative cellular injury, and favorably modulate the immune response [6]. 


\section{Justifications}

Feeding critically ill patients in the ICU is a controversial subject in many respects. Timing of feeding, caloric content, and protein content are all issues, and here, existing guidelines are based upon a low level of scientific evidence [7].

There are different approaches of support with their own benefits \& limitations. So, to optimize these benefits by minimizing the risk there should be a working guideline. And, this guideline helps to make nutritional management processes simple and easily understandable for workers during actual practice, to cope up for the possible complications of each approach with the simplified management guide.
There is no such guideline for the management of critically ill patients by nutrition in our hospital, Gondar university hospital.

\section{Methodology}

Evidences of this guideline were found through hinari/ PubMed/PMC, Google scholar and systematic review of Cochrane library search engines. Most of the evidences found through PubMed searching; and a total of 18 literatures were evaluated being pertinent for this guideline. When the term "Nutritional support for critically ill patients" in PubMed around 2605 articles were found, but different filtration methods were applied. Type of study (clinical trial \& meta-analysis), type articles (free full text) and time of publication (5 years later) were concerns for filtration. And after filtration 18 articles were taken (Table 1) (Figure 1).

Table 1: Articles level of evidence classification.

\begin{tabular}{|c|c|c|c|}
\hline No & Articles & Total Number \\
\hline 1 & $\begin{array}{c}\text { Systematic review, meta-analysis, } \\
\text { evidence-based guideline }\end{array}$ & 5 \\
\hline 2 & $\begin{array}{c}\text { Multicenter RCT, study protocol } \\
\text { for RCT }\end{array}$ & $1 \mathrm{~b}$ \\
\hline 3 & Single center RCT & 6 \\
\hline
\end{tabular}

Source: WHO GCP, University of Wisconsin, Madison, Health science, Ebling library and OHSU clinical inquiry council.

\section{Literature Review}

During literature reviewing interventions considered were timing of nutrition (early vs. late), route of administration (Enteral (NGT vs. NIT) vs Parenteral (TPN vs. PPN)) and Contents of the nutrition (EU caloric/target support vs Hypo caloric/underfeeding). And, the outcomes considered were Mortality (ICU, hospital, and long term), Length of stay (ICU and hospital), Quality of life, Specific complications. Some specific conditions of the reviewing were acute lung injury, GI operated patients, head injury, mechanically ventilated patients and literatures are discussed based on the considerations of the interventions and evaluated by the outcomes.

\section{Timing of support initiation}

A multicenter RCT which was done to compare early enteral and early parenteral initiation of nutrition on 2854 patients showed hemodynamic stability of the patients was an indication for the rout as well as the timing of initiation. If the patient is stable is better to start enteral nutrition early. This is based on the requirement of catecholamine and the level of arterial lactic acid. And if catecholamine is required and arterial lactic acid level $>2 \mathrm{mmol} / \mathrm{l}$ the patient needs to stay on parenteral support for 7 days. After while change to enteral at the 8th day [8].

Another multicenter coast analysis study aimed to compare early and late parenteral nutrition on the sample of 4640 patients showed that early parenteral nutrition was associated with anti-infection pharmacy related and other expenditure related high cost. The use of Early-PN in critically ill patients can thus not be recommended for both clinical (no benefit) and cost-related reasons [9].

Retrospective RCT of reviewing of 84 patients by grouping in early and late enteral feeding after GI surgery was done in Wonju, Yonsei university by clear inclusion \& exclusion criteria and resulted in; LOS in ICU \& hospital was decreased in early (within 48hrs) enteral nutrition and pulmonary complications were high in late (47.5\%) in comparison (13.6\%) (p=0.001) [10].

On other Cochrane review a total of 11 trials were included. Seven trials addressed the timing of support (early versus delayed), data on mortality were obtained for all seven trials (284 participants); the relative risk (RR) for death with early nutritional support was 0.67 (95\% CI 0.41 to 1.07). Data on disability were available for three trials; The RR for death or disability at the end of follow-up was 0.75 (95\% CI 0.50 to 1.11). Seven trials compared parenteral versus enteral nutrition. Because early support often involves parenteral nutrition, three of the trials are also included in the previous analyse sive trials (207 participants) reported mortality The RR for 
$\mathrm{Cl} 0.40$ to 1.19). One trial compared gastric versus jejunal enteral nutrition, there were no deaths and the RR was not estimable [11].

\section{Route}

A systematic review of 18 RCTs on 3347 patients was conducted to compare EN \& PN in terms of mortality, LOS \& infection complications. And resulted as; both routes has similar mortality $(\mathrm{p}=0.75)$ and LOS in hospital and on MV; but EN has reduced effect in LOS of ICU (0.0003) and infection complications ( $\mathrm{p}=0.004)$ [3].

After $72 \mathrm{hrs}$ of 1 st line PN we should consider EN based on hemodynamic evaluation. If stable (no vasoactive drugs for $24 \mathrm{hrs} \&$ arterial lactic acid $<2 \mathrm{mmol} / \mathrm{l}$ ), PN can be stop and immediately EN should be started. If still need of vasoactive drugs \& arterial lactic acid $>2 \mathrm{mmol} / \mathrm{l}$, PN continue for 7 days. At the 8th day PN stop \& EN start. But PN may be added if persistent intolerance for EN exists [8].

A pragmatic RCT from New England journal of medicine on 2400 patients was conducted to compare EN \& PN. As a result, it showed

that PN is associated with reduced risk of hypoglycemia $(\mathrm{p}=0.006)$ and vomiting $(\mathrm{p}<0.001)$. But there was no significant difference in infection complication $(\mathrm{p}=0.72)$ and 90 -day mortality $(\mathrm{p}=0.4)$ between the two groups [4].

There are different ways to administer EN. These are post pyloric/NIT and gastric/NGT. And a study done in china on 75 patients by RCT to compare the effect of NIT after blind bedside placement and NGT on nutritional status and complications of nutrition for critically ill patients. As a result, this article shows that bloating, diarrhea, upper GI bleeding and liver damage has no significant difference in the two groups $(p>0.05)$. But risk of reflux and pneumonia, duration of MV, LOS in ICU and nutritional support costs are significantly reduced in NIT nutritional route $(\mathrm{p}<0.01)[1]$.

Another systematic review of 9 RCTs on 522 patients in USA showed that the incidence of pneumonia, ICU LOS, mortality \& caloric goals achieved were similar in both gastric and post pyloric feeding. But there may be delay in post pyloric tube insertion \& so gastric feeding may initiated earlier [12].

A systematic review and meta-analysis of 15 level-2 studies were included. Small bowel feeding was associated with a reduced risk of pneumonia (Relative Risk, RR, small intestinal vs. intragastric: 0.75 (95\% confidence interval 0.60 to 0.93$)$; ( $\mathrm{P}=0.01)$. Duration of ventilation (WMD: -0.36 days ( -2.02 to 1.30$)$; $\mathrm{P}=0.65)$, length of ICU stays (WMD: 0.49 days, $(-1.36$ to 2.33$) ; \mathrm{P}=0.60)$ and mortality (RR 1.01 ( 0.83 to 1.24 ); $\mathrm{P}=0.92$ ) were unaffected by the route of feeding. While data were limited, and there was substantial statistical heterogeneity, there was significantly improved nutrient intake via the small intestinal route (\% goal rate received: $11 \%$ (5 to $16 \%$ ); $\mathrm{P}=0.0004$ ) [13].

Another systematic review and meta-analysis which included 19 trials with 1394 patients aimed to compare the effect of small bowel feeding with gastric feeding on the frequency of pneumonia and other patient-important outcomes in critically ill patients. And showed that; Small bowel feeding compared to gastric feeding was associate with reduced risk of pneumonia and ventilator associated pneumonia (RR 0.70; 95\% CI, 0.55, 0.90; P=0.004) \& (RR 0.68; 95\% CI 0.53, 0.89; $\mathrm{P}=0.005$; I2=0\%) respectively. But has no significant difference in mortality (RR 1.08; 95\% CI 0.90 ,
1.29; P=0.43; I2=0\%), LOS in ICU (WMD-0.57; 95\% CI-1.79, 0.66; $\mathrm{P}=0.37 ; \mathrm{I} 2=0 \%$ ), duration of mechanical ventilation (WMD-1.01; 95\% CI $-3.37,1.35 ; \mathrm{P}=0.40 ; \mathrm{I} 2=17 \%$ ), gastrointestinal bleeding (RR 0.89; 95\% CI 0.56, 1.42; P=0.64; I2=0\%), aspiration (RR 0.92; $95 \%$ CI 0.52, 1.65; P=0.79; I2=0\%), and vomiting (RR 0.91; 95\% CI $0.53,1.54 ; \mathrm{P}=0.72 ; \mathrm{I} 2=57 \%)$. The overall quality of evidence was low for pneumonia outcome [5].

As this prospective, multicenter, open-label, randomized, controlled clinical trial showed that prokinetic agents were effective to improve post pyloric placement of nasojejunal tubes in critically ill patients ( $p=0.0001)$ [14] and used for treatment of GI intolerance during EN [8].

\section{Contents}

A randomized control study of 83 surgical ICU patients done to compare the effect of EU caloric and hypo caloric nutritional support on rate of infection showed that EU caloric nutrition (25$30 \mathrm{kcal} / \mathrm{kg} /$ day) has reduced effects on acquisition of infection, LOS in ICU \& hospital and mortality in comparison with the hypo caloric groups like; risk of infection $(70.7<76.2)$, LOS in ICU $(13.5 \pm 1.1 \mathrm{~d}<16.7 \pm 2.7 \mathrm{~d})$, hospital stay $(31.0 \pm 2.5<35.2 \pm 4.9 \mathrm{~d})$. therefore, even if the difference is not significant it is better to use EU caloric nutritional support for critically ill patients [6].

Hypo caloric feeding was associated with more negative protein balance with no difference in amino acid oxidation and whole-body protein synthesis was lower during hypo caloric feeding by phenylalanine tracer [7].

Another meta-analysis indicates that high-energy intake does not improve outcomes and may increase complications in critically ill patients who are not malnourished. So, the act of nutritional support needs pre-evaluation of the patient's nutritional status. Initial moderate nutrient intake (33.3 to $66.6 \%$ of goal energy), compared to high energy, may reduce mortality, and a higher protein intake combined with high energy $\geq 0.85 \mathrm{~g} / \mathrm{kg}$ per day) may decrease the infection rate. But the contribution of energy versus protein intake to outcomes remains unclear [15].

In addition to this other study showed the comparison between permissive under feeding and standard nutritional support as no significant difference in association with 90-d 
mortality, in feeding intolerance, diarrhea and infections and LOS in ICU \& hospital [16].

A study aimed to evaluate the effect of concentrated EN solution on calorie delivery showed that the substitution of a $1.0 \mathrm{kcal} / \mathrm{ml}$ with a $1.5 \mathrm{kcal} / \mathrm{ml}$ EN solution administered at the same rate $(1 \mathrm{ml} / \mathrm{kg})$ resulted in a $46 \%$ greater calorie delivery without any adverse effects [17].

\section{Controversy}

There are different articles which has different perspectives of nutritional support in terms of timing, route and contents. From those the followings are some the literatures.

A research from New England journal of medicine supports the route of PN nutritional support since it has low risk of vomiting and hypoglycemia. But others stated that EN has superior advantages than PN with preventive mechanisms of such complications by using NIT and calculated calorie intake for those critically ill patients.

\section{Nutritional screening for all ICU patients}

Screen all ICU admissions to assess need for nutrition support. Screening should be performed by a suitably qualified multidisciplinary team member, e.g. intensive care dietitian, anesthetist, or nurse. The assessment usually includes:
a) Evaluation of weight loss
b) Previous nutrient intake
c) Level of disease severity
d) Co morbid conditions
e) Function of the gastrointestinal tract
f) Serum Albumin level
g) Daily nitrogen balance

Consider nutrition support for:

a) Malnourished, or hyper catabolic patients, or those at risk of malnutrition.

b) Ill patients with expected ICU stay of $\geq 3$ days.

c) PO diet not expected for $\geq 5$ days.

\section{Confirming enteral feeding tube position}

Only use radio-opaque tubes for enteral feeding. Obtain radiographic confirmation that any blindly placed tube (small or large bore) is properly positioned in the GI tract prior to its initial use for administration of feed or medications. Bedside $\mathrm{pH}$ checks can also be used to check position

Mark the exit site of a feeding tube at the time of initial placement. Observe for a change in the external tube length during feeding.
In adult patients do not rely on the auscultator method to differentiate between gastric and respiratory placement of feeding tube.

\section{Feed type and administration}

Standard polymeric feeds can be used for most ICU patients. Standard ICU feeds can be $1 \mathrm{kcal} / \mathrm{ml}$ up to $1.5 \mathrm{kcal} / \mathrm{ml}$ and consider additional micronutrient supplementation. It is better to use sterile water for flushing tubes or for enteral water infusion. Sterile liquid formulas should be used in preference to powdered reconstituted feeds. The hung time for sterile decanted formulas and reconstituted powdered feeds should have a maximum of 8 \& 4 hours respectively [18].

Consider fine bore NG feeding tubes when patient is stable on NG feeds and all aspirates are normal. EN prescriptions should include patient identifiers, the feed formula, the enteral access device/site, and the administration method and rate.

A head-of-bed elevation of 30-45 degree is recommended during feeding, unless contra-indicated. EN can commence in surgical patients without waiting for flatus or a bowel motion.

Preparation of the enteral formula (feed) should be done in a clean environment using hygienic technique by trained personnel (nurse/pharmacist). Purified water (boiled cooled water) or sterile water should be used for irrigation/flushes, reconstitution of formula \& dilution of medication. Sterile gloves should be used when handling and administering enteral feeds and all efforts must be taken to minimize contamination [19] 1a.

Different administration approaches [19].

a) Bolus administration: $200-400 \mathrm{ml}$ of feeds over $15-60$ minutes by $50 \mathrm{ml}$ syringe at regular interval.

b) Intermittent administration: break in feeding of $6 \mathrm{hrs}$ or more based on patient needs.

c) Continuous feed: prevents diarrhea/dumping but results in higher intragastric $\mathrm{pH}$ levels than bolus

\section{Feeding complications}

Feeding critically ill patients may associate with different complications due to timing, route, the content and amount of the feed. And hypoglycemia, vomiting, diarrhea, infection, gastric reflux, aspiration pneumonia, over feeding syndrome are some of the common complications. Therefore, it is better to know these things and early diagnose and treatment is mandatory to improve the patient's outcome.

\section{Discussion}

Different routes of administration have their own benefits and limitations. Parenteral nutrition has benefits of decreases risk of vomiting and hypoglycemia. But Enteral nutrition with the approach of using target calorie/EU caloric, post pyloric tubes/ NIT and Prokinetic agents has superior effect over parenteral 
nutrition in all outcomes

Based on the above approaches benefits of EN are; Improve nutritional status, reduce feeding complications, decrease nutritional coast, decrease infectious complications and reduce LOS of ICU, hospital \& MV. And from different approaches of EN we can choose the one from the following based on their benefits \& limitations

a) NGT - is easy to secure \& administration but has risk of GI reflux and aspiration

b) NIT - is advantages to decrease risk of reflux \& aspiration with $94.3 \%$ of success to secure it in bade side.

\section{Conclusions}

\section{Appendix 1: Patient assessment for nutritional requirement}

Screen all ICU admissions to assess need for nutrition support. Screening should be performed by a suitably qualified multidisciplinary team member, e.g. intensive care dietitian, anesthetist, or nurse (Table 2) (Figure 2 \& 3)

The assessment usually includes:
a) Evaluation of weight loss
b) Previous nutrient intake
c) Level of disease severity
d) Co morbid conditions
e) Function of the gastrointestinal tract
f) Serum Albumin level
g) Daily nitrogen balance

Consider nutrition support for:

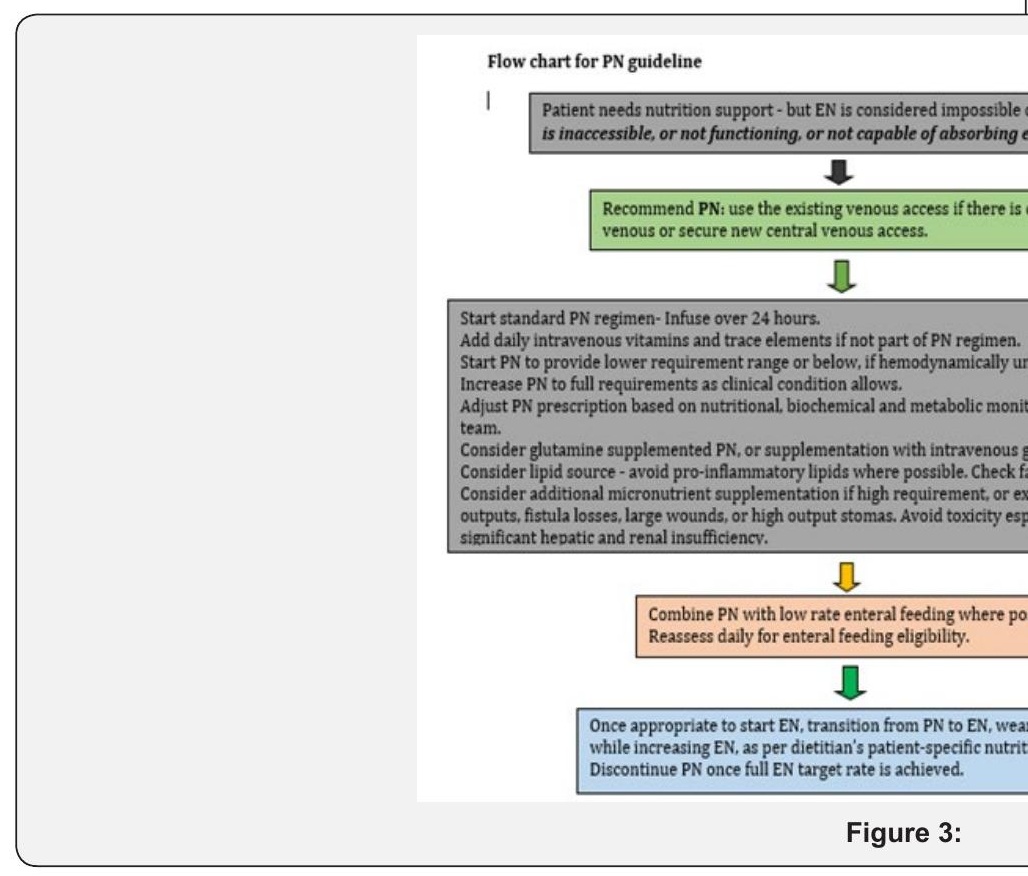

\section{Appendix 2: Recommended macronutrients for ICU patients (what $\&$ how to give)}

Table 3: Calculations of macronutrients need.

\begin{tabular}{|c|c|}
\hline Required Nutrients & Amount \\
\hline Energy & $20-30 \mathrm{kcal} / \mathrm{kg} / \mathrm{day}$ \\
\hline Lipid & $30-35 \%$ of total calorie in \\
\hline Carbohydrate & $50-55 \%$ of total calorie in \\
\hline Protein & $\begin{array}{r}1.2-1.5 \mathrm{~g} / \mathrm{kg} / \text { day } \text { (extra loss shoul } \\
\text { but not }>2 \mathrm{~g} / \mathrm{kg} / \text { day }\end{array}$ \\
\hline
\end{tabular}

What to give? (Table 3)

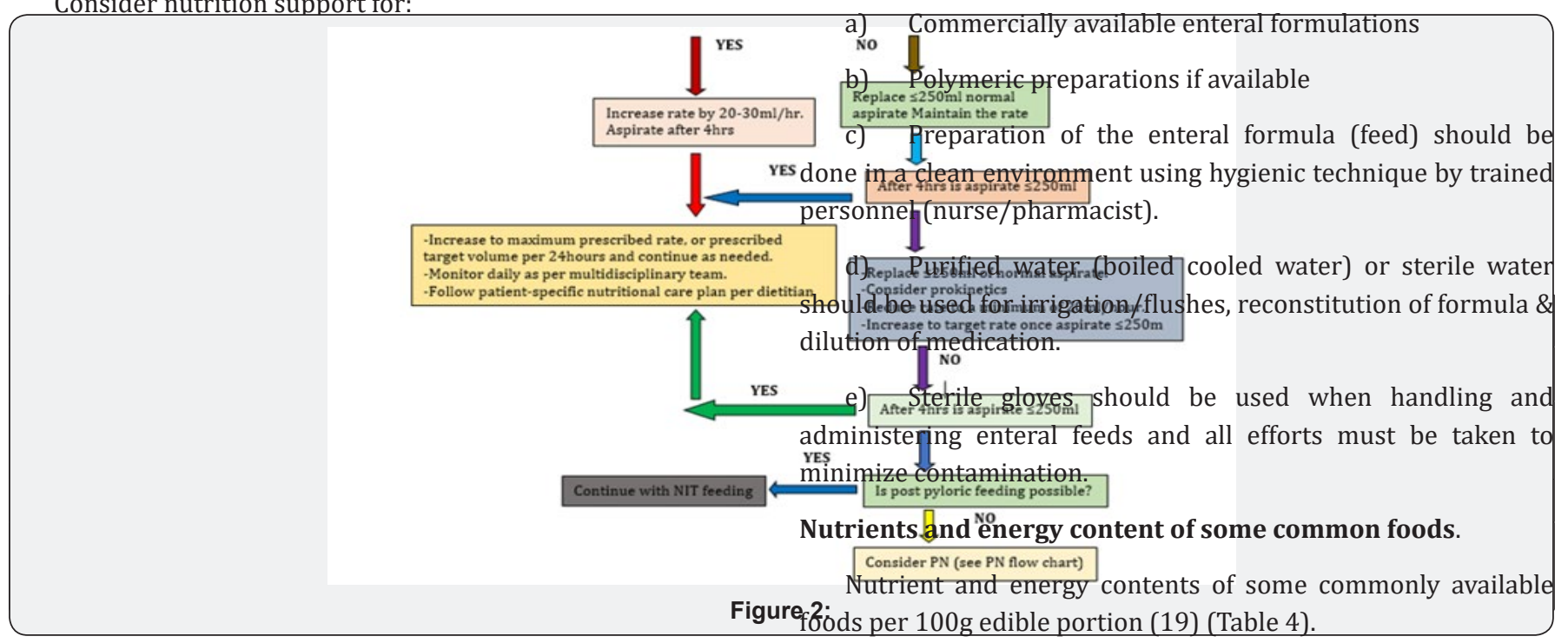


Table 4: Table some available foods.

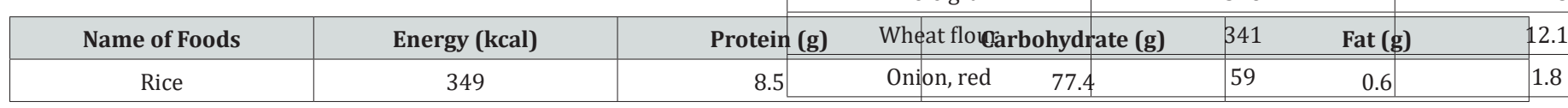

\begin{tabular}{|c|c|c|c|c|}
\hline Potato & 97 & 1.6 & 22.6 & 0.1 \\
\hline Cabbage & 27 & 1.8 & 4.6 & 0.1 \\
\hline Carrot leaves & 77 & 5.1 & 18.1 & 0.5 \\
\hline Mango & 44 & 0.7 & 10.1 & 0.1 \\
\hline Papaya & 27 & 0.7 & 5.7 & 0.2 \\
\hline Ripe tomato & 20 & 0.9 & 3.6 & 0.2 \\
\hline Apple & 59 & 0.2 & 18.4 & 0.5 \\
\hline Avocado pear & 215 & 1.7 & 0.8 & 22.8 \\
\hline
\end{tabular}

\begin{tabular}{|c|c|c|c|c|}
\hline Banana ripe & 116 & 1.2 & 27.2 & 0.8 \\
\hline Lemon & 57 & 1 & 11.1 & 0.9 \\
\hline Mango ripe & 74 & 0.6 & 16.9 & 0.4 \\
\hline Orange juice & 9 & 0.2 & 1.9 & 0.1 \\
\hline Caw's milk & 67 & 3.2 & 4.4 & 4.1 \\
\hline Milk powdered & 496 & 25.8 & 38 & 26.7 \\
\hline Butter & 729 & - & - & 81 \\
\hline Cheese & 348 & 24.1 & 6.8 & 25.1 \\
\hline Ice cream & 140 & 4 & 28.8 & 3.5 \\
\hline Beef & 262 & 10 & - & 14 \\
\hline Goat liver & 107 & 20 & - & 3 \\
\hline Goat meat & 118 & 21.4 & - & 3.6 \\
\hline Egg white, hen & 52 & 10.7 & 1.1 & 0.2 \\
\hline Egg yolk, hen & 336 & 16.8 & - & 29 \\
\hline Coconut oil & 883 & - & - & 99.9 \\
\hline Olive oil & 980 & - & - & 99.9 \\
\hline Soybean oil & 883 & - & - & 99.99 \\
\hline Bee's honey & 319 & 0.3 & 79.5 & - \\
\hline Sugar brown & 389 & 0.2 & 97 & - \\
\hline Sugar white & 400 & - & 100 & - \\
\hline Barley, black- flour & 370.9 & 10.1 & 78.8 & 1.7 \\
\hline “" - enjera & 124.9 & 3.4 & 27.6 & 0.1 \\
\hline "“ - bread & 195.5 & 5.1 & 42.9 & 0.4 \\
\hline " " - porridge & 150.3 & 2.4 & 21 & 6.3 \\
\hline "white - flour & 368 & 8.5 & 82.8 & 2 \\
\hline “" - enjera & 125.8 & 2.6 & 28.4 & 0.2 \\
\hline Barley, white- bread & 202.4 & 4.4 & 45.3 & 0.4 \\
\hline “" - porridge & 134.7 & 2.1 & 19.2 & 5.5 \\
\hline Maize, white- flour & 378.2 & 9 & 75.2 & 4.6 \\
\hline " " - enjera & 153 & 3.6 & 32.4 & 1 \\
\hline “" - bread & 223.4 & 4.1 & 46.4 & 2.2 \\
\hline "“ - porridge & 154.7 & 2.4 & 23.9 & 5.5 \\
\hline
\end{tabular}


Journal of Anesthesia \& Intensive Care Medicine

\begin{tabular}{|c|c|c|c|c|c|}
\hline Ehriner wheat- flour & \multirow{2}{*}{\multicolumn{2}{|c|}{$\begin{array}{cc}1.5 & 379 \\
1.7 & 239.3 \\
\end{array}$}} & \multirow{2}{*}{$\begin{array}{c}12.7 \\
7.5 \\
\end{array}$} & \multirow{2}{*}{$\begin{array}{l}76.6 \\
50.3 \\
\end{array}$} & \multirow{2}{*}{$\begin{array}{l}2.5 \\
0.9 \\
\end{array}$} \\
\hline 69.4 “" - bread & & & & & \\
\hline 12.6 “ - porridge & 0.1 & 140.7 & 3.3 & 21.3 & 4.7 \\
\hline Millet, black - flour & \multicolumn{2}{|r|}{350.4} & 6.4 & 78.5 & 1.2 \\
\hline ““ - enjera & \multicolumn{2}{|r|}{156.1} & 2.9 & 35 & 0.5 \\
\hline "“ - bread & \multicolumn{2}{|r|}{216.5} & 4 & 49 & 0.5 \\
\hline “" - porridge & \multicolumn{2}{|r|}{154.7} & 2.5 & 23.8 & 5.5 \\
\hline Tef, red - flour & \multicolumn{2}{|r|}{355.1} & 9 & 73.1 & 2.7 \\
\hline
\end{tabular}

\begin{tabular}{|c|c|c|c|c|c|c|c|c|}
\hline “ “ - enjera & 155.9 & 3.4 & "“- & enjera & 34 & 147.7 & 0.7 & 4. \\
\hline " " - bread & 220 & 5.4 & " " - & bread & 46.9 & 205.3 & 1.2 & 5. \\
\hline “" - porridge & 165.4 & 2.2 & $" u-p$ & porridge & 22.5 & 153.3 & 7.4 & 2. \\
\hline Tef, white - flour & 358.8 & 9.3 & "whit & te - flour & 75 & 362.9 & 2.4 & 10. \\
\hline “" - enjera & 145 & 3 & "“- & enjera & 31.9 & 145.6 & 0.3 & 3. \\
\hline "“ - bread & 214.3 & 5 & "“- & bread & 48.1 & 222 & 1.1 & 6. \\
\hline “" - porridge & 193.7 & 2.2 & " " - p & porridge & 12.6 & 142.7 & 14.5 & 3. \\
\hline Wheat, black - flour & 353.8 & 10.5 & Bea & n flour & 74.8 & 349.8 & 1.4 & 23 \\
\hline Chickpea flour & 383.4 & 19.4 & & & 63.4 & & 5.8 & \\
\hline Lentil flour & 356.6 & 21.8 & & & 66 & & 0.6 & \\
\hline Peas & 352.2 & 20.1 & & & 64.8 & & 1.4 & \\
\hline
\end{tabular}

Source: Ethiopian food composition table part III and Collage of anesthesiologist in Sir Lanka, nutritional support guideline, 2014

\section{Macronutrients recommendation (Table 5)}

Table 5:_specific considerations of macronutrients.

\begin{tabular}{|c|c|c|}
\hline Nutrient & Recommendation & Guideline Source \\
\hline Energy & Individualize. & \\
\hline \multirow[t]{3}{*}{$\begin{array}{l}\text { Use validated equations, in the absence of } \\
\text { indirect calorimetry. }\end{array}$} & Irish nutritional support guideline 2012 & \\
\hline & $\begin{array}{l}\text { Use } 25-30 \mathrm{kcal} / \mathrm{kg} \text {, or predictive equations, or } \\
\text { indirect calorimetry. }\end{array}$ & \\
\hline & $20-25 \mathrm{kcal} / \mathrm{kg}$ in acute phase of critical illness. & \\
\hline \multicolumn{3}{|l|}{$25-30 \mathrm{kcal} / \mathrm{kg}$ in recovery phase. } \\
\hline & $\begin{array}{c}\text { Consider hypo caloric feeding in critically ill } \\
\text { obese (BMI }>30 \mathrm{~kg} / \mathrm{m} 2) \text {, e.g. } 60-70 \% \text { of target } \\
\text { energy requirements, or } 11-14 \mathrm{kcal} / \mathrm{kg} \text { actual } \\
\text { body weight, or } 22-25 \mathrm{kcal} / \mathrm{kg} \text { ideal body } \\
\text { weight. }\end{array}$ & \\
\hline \multirow[t]{2}{*}{ Protein } & $1.3-1.5 \mathrm{~g}$ protein $/ \mathrm{kg}$. & Irish nutritional support guideline 2012 \\
\hline & $1.2-2.0 \mathrm{~g}$ protein $/ \mathrm{kg}$ if $\mathrm{BMI}<30 \mathrm{~kg} / \mathrm{m} 2$. & \\
\hline \multicolumn{3}{|l|}{$2 \mathrm{~g} / \mathrm{kg}$ ideal weight if BMI $30-40 \mathrm{~kg} / \mathrm{m} 2$. } \\
\hline \multicolumn{3}{|l|}{$2.5 \mathrm{~g} / \mathrm{kg}$ ideal weight if $\mathrm{BMI}>40 \mathrm{~kg} / \mathrm{m} 2$. } \\
\hline & Caution with excess nitrogen in severely ill. & \\
\hline \multirow[t]{2}{*}{ Glucose } & Minimum 2g/kg & Irish nutritional support guideline 2012 \\
\hline & $\begin{array}{l}\text { Maximal glucose oxidation rate is } 4-7 \mathrm{mg} / \mathrm{kg} / \\
\text { minute/ } 24 \text { hours. }\end{array}$ & \\
\hline Ideally keep to $\leq 5 \mathrm{mg} / \mathrm{kg} / \mathrm{minute} / 24$ hours. & & \\
\hline
\end{tabular}




\begin{tabular}{|c|c|c|}
\hline & $3-5$ (maximum 7$) \mathrm{g} / \mathrm{kg}$. & \\
\hline Fat/lipid & $0.7-1.5 \mathrm{~g} / \mathrm{kea}$. & Irish nutritional support guideline 2012 \\
\hline & $0.8-1 \mathrm{~g} / \mathrm{kg}$ in sepsis/SIRS. & \\
\hline & Consider lipid source. & \\
\hline
\end{tabular}

NB: Do not exceed the maximum handling capacity for carbohydrate or lipid. Consider all lipid sources, e.g. propofol, and carbohydrate sources, e.g. glucose infusions and dialysate solutions, when calculating energy provision.

\section{Appendix 3: Placement \& confirmation of feeding tubes}

a) Explain the procedure to the patient if conscious.

b) Always use a radio opaque tube in ICU patients (if available).

c) Orogastric tubes are preferred for patients with head or maxillofacial injury.

d) Mark the tube at a distance equal to that from xiphisternum to the nose via the ear lobe $(50-60 \mathrm{~cm})$

e) Lubricate the tube externally with gel or water.

f) Check nasal patency (if possible) by "sniff" with each nostril occluded in turn. Clear nostril can be sprayed with lignocaine to minimize discomfort.

g) Sit patient upright with the head level. Slide tube gently backwards along the floor of the clear nostril until visible at the back of the pharynx $(10-15 \mathrm{~cm})$.

h) If the patient is co-operative, ask them to take a mouthful of water \& then advance the tube $(5-10 \mathrm{~cm})$ as they swallow.

i) Repeat the water swallow/advance until the preset mark on the tube reaches the nostril.

j) Withdraw the tube at any stage if the patient is distressed/coughing or cyanosed.

k) If there is difficulty in passing the tube, ask the patient to tilt the head forwards or turn it to one side. Never push the tube against resistance.

l) Check position of the NG tube.

i. $\quad \mathrm{pH}$ testing - $\mathrm{pH} 5.5$ or less (if $\mathrm{PH}$ testing strips are available).

ii. X-ray -checking the position of the tube by injecting air through it \& listening for bubbles with a stethoscope is unreliable.

m) Documentation.

i. Size of the tube.

ii. Length at entry/ length from entry point to end of the tube (external tube length).

iii. Method/s used to confirm the position. n) Check \& document pH \& external tube length, at least twice per 24 hours and if continuous feeds are being given, during the rest period.

\section{Appendix 4: Possible feeding complications}

a) Hypo/hyper-glycemia

b) Diarrhea

c) Gastric reflux

d) Over feeding syndrome

e) Vomiting

f) Aspiration pneumonia

g) Infection

\section{Appendix 5: feeding considerations for specific disease conditions}

\section{Obese patient}

In Critically ill obese patient, permissive underfeeding or hypocaloric feeding with enteral nutrition is recommended.

\section{Pancreatitis}

a) Patients with acute pancreatitis should be evaluated for disease severity on admission.

b) Patients with severe acute pancreatitis should have a naso-enteric tube placed and EN initiated as soon as fluid volume resuscitation is completed. These patients have minimal chance of establishing oral feeds within 7 days.

c) Patients with severe acute pancreatitis will have improved outcome when provided early EN. These patients may be feed enterally by the gastric or jejunal route

d) For patients with severe acute pancreatitis when EN is not feasible, use of PN should be considered. PN should not be initiated until after the first 5 days of hospitalization, during which period EN should be attempted repeatedly

\section{Renal Failure}

a) Should be placed on standard enteral formulations, and standard ICU recommendations for protein and calorie provisions should be followed. If significant electrolyte abnormalities exist or develop, a special formulation designed for renal failure may be considered. i.e. Special formulations lower in certain electrolytes 
than standard products may be beneficial in the ICU patient with ARF.

b) Patients receiving hemodialysis or continuous renal replacement therapy should receive increased protein, up to a maximum of $2.5 \mathrm{~g} / \mathrm{kg} /$ day

\section{Pulmonary Failure}

a) Specialty high lipid low carbohydrate formulations designed to manipulate the respiratory quotient and reduce $\mathrm{CO} 2$ production is not recommended for routine use in ICU patients with acute respiratory failure.

b) Avoid total caloric provision that exceeds energy requirements, as $\mathrm{CO} 2$ production increases significantly with lipogenesis.

c) Fluid restricted calorically dense formulations should be considered for patients with acute respiratory failure

\section{Appendix 6: Practical recommendations}

a) Evaluate all enterally fed patients for risk of aspiration

b) Ensure that the feeding tube is in the proper position before initiating feeding and every time the patient is fed.

c) Keep the head of the bed elevated at 30-45 degrees at all times during the administration of enteral feeding.

d) When possible, use a large-bore tube only for the first 1-2 days of enteral feeding (as there is an increased risk of sinusitis \& discomfort with large bore tubes) \& evaluate the gastric residual volume (GRV) using a $50 \mathrm{ml}$ syringe.

e) Check GRV every $4 \mathrm{hrs}$ during the first 48 hours for gastrically fed patients. Once the enteral feeding goal rate is achieved and/or the large bore tube is replaced with a softer small-bore feeding tube, GRV monitoring may be reduced to every 6-8 hours in non-critically ill patients. However, every 4-hour measurements are prudent in critically ill patients

f) If the GRV is $>250 \mathrm{ml}$ after a second gastric residual check, a pro-motility agent should be considered in adult patients, if there are no contraindications. Discontinue pro-motility agents after 24-48 hours if ineffective and they should not be used routinely.

g) A GRV of $>500 \mathrm{ml}$ persistently should result in holding or reducing the enteral nutrition (EN) temporarily\& re-assessing the patient's tolerance.

h) Tolerance can be enhanced by minimizing sedation, reducing opiate use, maintaining serum potassium within normal limits, especially avoiding hypokalemia and controlling hyperglycemia.

i) Consider post pyloric feeding, when the GRV consistently remains $>500 \mathrm{ml}$.

j) Increase feed only as tolerated, observing for any signs of vomiting, nausea, regurgitation \&abdominal discomfort/ distension.

\section{Appendix 7: Summary of literatures (Table 6)}

Table 6: Literatures summary.

\begin{tabular}{|c|c|c|c|c|}
\hline No & Title & Methodology & No of Sample & Publication Year \\
\hline 1. & $\begin{array}{l}\text { Enteral versus parenteral nutrition in } \\
\text { critically ill patients : }\end{array}$ & $\begin{array}{l}\text { Systematic review and meta-analysis of } \\
\text { randomized controlled trials }\end{array}$ & 18 RCTS (3347 pts) & 2016 \\
\hline 2. & $\begin{array}{l}\text { Permissive Underfeeding or Standard } \\
\text { Enteral Feeding in Critically Ill Adults }\end{array}$ & RCT & 894 pts & 2015 \\
\hline 3 & $\begin{array}{l}\text { Whole body protein kinetics during } \\
\text { hypocaloric and normocaloric feeding in } \\
\text { critically ill patients }\end{array}$ & Study protocol of RCT & $16 \mathrm{pts}$ & 2013 \\
\hline 4 & $\begin{array}{l}\text { Impact of early enteral versus parenteral } \\
\text { nutrition on mortality in patients } \\
\text { requiring mechanical ventilation and } \\
\text { catecholamine }\end{array}$ & $\begin{array}{l}\text { Multi center, open labeled, parallel group } \\
\text { RCT }\end{array}$ & 2854 pts & 2014 \\
\hline 5 & $\begin{array}{l}\text { Hypocaloric compared with eucaloric } \\
\text { nutritional support and its effect on } \\
\text { infection rates in a surgical intensive } \\
\text { care unit }\end{array}$ & RCT & $83 \mathrm{pts}$ & 2014 \\
\hline 6 & $\begin{array}{l}\text { Bedside Calculation of Energy } \\
\text { Expenditure Does Not Guarantee } \\
\text { Adequate Caloric Prescription in Long- } \\
\text { Term Mechanically Ventilated Critically } \\
\text { Ill Patients }\end{array}$ & Observational & $50 \mathrm{pts}$ & 2012 \\
\hline 7 & $\begin{array}{l}\text { Trial of the Route of Early Nutritional } \\
\text { Support in Critically Ill Adults }\end{array}$ & Pragmatic RCT & $2400 \mathrm{pts}$ & 2014 \\
\hline
\end{tabular}




\begin{tabular}{|c|c|c|c|c|}
\hline 8 & $\begin{array}{l}\text { Metoclopramide or domperidone } \\
\text { improves post-pyloric placement of } \\
\text { spiral nasojejunal tubes in critically ill } \\
\text { patients }\end{array}$ & $\begin{array}{l}\text { a prospective, multicenter, open-label, } \\
\text { randomized, controlled clinical trial }\end{array}$ & $307 \mathrm{pts}$ & 2015 \\
\hline 9 & $\begin{array}{l}\text { Early Feeding Is Feasible after } \\
\text { Emergency Gastrointestinal Surgery }\end{array}$ & Retrospective RCT & $84 \mathrm{pts}$ & 2013 \\
\hline 10 & $\begin{array}{c}\text { Use of a concentrated enteral nutrition } \\
\text { solution to increase calorie delivery to } \\
\text { critically ill patients }\end{array}$ & $\begin{array}{l}\text { Prospective, randomized, double blind, } \\
\text { parallel, multi center study }\end{array}$ & $112 \mathrm{pts}$ & 2014 \\
\hline 11 & $\begin{array}{l}\text { Supplemental parenteral nutrition in } \\
\text { critically ill patients }\end{array}$ & $\begin{array}{l}\text { A study protocol for a phase II } \\
\text { randomized controlled trial }\end{array}$ & $100 \mathrm{pts}$ & 2015 \\
\hline 12 & $\begin{array}{l}\text { Early versus late parenteral nutrition in } \\
\text { ICU patients }\end{array}$ & $\begin{array}{l}\text { Multi center cost analysis of the EPaNIC } \\
\text { trial }\end{array}$ & $4640 \mathrm{pts}$ & 2012 \\
\hline 13 & $\begin{array}{l}\text { Early jejunal feeding by bedside } \\
\text { placement of NIT improves nutritional } \\
\text { status \& significantly reduce } \\
\text { complications in critically ill patients vs } \\
\text { enteral by NGT }\end{array}$ & RCT & $70 \mathrm{pts}$ & 2015 \\
\hline 14 & $\begin{array}{c}\text { Small bowel feeding and risk of } \\
\text { pneumonia in adult critically ill patients: }\end{array}$ & $\begin{array}{l}\text { a systematic review and meta-analysis of } \\
\text { randomized trials }\end{array}$ & 19 trials/ $1934 \mathrm{pts}$ & 2013 \\
\hline 15 & $\begin{array}{l}\text { Enteral nutrition therapy for critically ill } \\
\text { adult patients: }\end{array}$ & critical review and algorithm creation & & \\
\hline 16 & $\begin{array}{l}\text { Comparisons between intragastric } \\
\text { and small intestinal delivery of enteral } \\
\text { nutrition in the critically ill: }\end{array}$ & a systematic review and meta-analysis & 15 level 2 studies & 2013 \\
\hline 17 & Gastric versus post-pyloric feeding: & a systematic review & 9 RCTS/ 522 pts & 2003 \\
\hline 18 & $\begin{array}{l}\text { Effect of initial calorie intake via enteral } \\
\text { nutrition in critical illness: }\end{array}$ & $\begin{array}{c}\text { a meta-analysis of randomized controlled } \\
\text { trials }\end{array}$ & 8 RCTS/ 1895 pts & 2015 \\
\hline
\end{tabular}

\section{References}

1. Wan B, Fu H, Yin J (2015) Early jejunal feeding by bedside placement of a nasointestinal tube significantly improves nutritional status and reduces complications in critically ill patients versus enteral nutrition by a nasogastric tube. Asia Pac JCl Nu 24(1): 51-57.

2. Araújo Junqueira L, De Souza DA (2012) Enteral nutrition therapy for critically ill adult patients: Critical review and algorithm creation. Nutr Hosp 27(4): 999-1008.

3. Elke G, van Zanten AR, Lemieux M, McCall M, Jeejeebhoy KN, et al. (2016) Enteral versus parenteral nutrition in critically ill patients: an updated systematic review and meta-analysis of randomized controlled trials. Crit Care 20(1): 117.

4. Harvey SE, Parrott F, Harrison DA, Bear DE, Segaran E, et al. (2014) Trial of the route of early nutritional support in critically ill adults. $\mathrm{N}$ Engl J Med 371(18): 1673-1684.

5. Alhazzani W, Almasoud A, Jaeschke R, Lo BW, Sindi A, et al. (2013) Small bowel feeding and risk of pneumonia in adult critically ill patients: A systematic review and meta-analysis of randomized trials. Crit Care 17(4): R127.

6. Charles EJ, Petroze RT, Metzger R, Hranjec T, Rosenberger LH, et al. (2014) Hypocaloric compared with eucaloric nutritional support and its effect on infection rates in a surgical intensive care unit: A randomized controlled trial. Am J Clin Nutr 100(5): 1337-1343.

7. Berg A, Rooyackers O, Bellander BM, Wernerman J (2013) Whole body protein kinetics during hypocaloric and normocaloric feeding in critically ill patients. Crit Care 17(4): R158.

8. Brisard L, Le Gouge A, Lascarrou JB, Dupont H, Asfar P, et al. (2014) Impact of early enteral versus parenteral nutrition on mortality in patients requiring mechanical ventilation and catecholamines: Study protocol for a randomized controlled trial (NUTRIREA-2). Trials 15: 507.

9. Vanderheyden S, Casaer MP, Kesteloot K, Simoens S, De Rijdt T, et al. (2012) Early versus late parenteral nutrition in ICU patients: Cost analysis of the EPaNIC trial. Crit Care 16(3): R96.

10. Lee HS, Shim H, Jang JY, Lee H, Lee JG (2014) Early feeding is feasible after emergency gastrointestinal surgery. Yonsei Med J 55(2): 395-400.

11. Perel P, Yanagawa T, Bunn F, Roberts IG, Wentz R, et al. (2006) Nutritional support for head-injured patients. Cochrane Database Syst Rev (4): CD001530.

12. Marik PE, Zaloga GP (2003) Gastric versus post-pyloric feeding: A systematic review. Crit Care 7(3): R46-51.

13. Deane AM, Dhaliwal R, Day AG, Ridley EJ, Davies AR, et al. (2013) Comparisons between intragastric and small intestinal delivery of enteral nutrition in the critically ill: a systematic review and metaanalysis. Crit Care 17(3): R125.

14. Hu B, Ye H, Sun C, Zhang Y, Lao Z, et al. (2015) Metoclopramide or domperidone improves post-pyloric placement of spiral nasojejunal tubes in critically ill patients: a prospective, multicenter, open-label, randomized, controlled clinical trial. Crit Care 19: 61.

15. Tian F, Wang X, Gao X, Wan X, Wu C, et al. (2015) Effect of initial calorie intake via enteral nutrition in critical illness: a meta-analysis of randomised controlled trials. Crit Care 19: 180.

16. Arabi YM, Aldawood AS, Haddad SH, Al-Dorzi HM, Tamim HM, et al. (2015) Permissive Underfeeding or Standard Enteral Feeding in Critically Ill Adults. N Engl J Med 372: 2398-2408.

17. Peake SL, Davies AR, Deane AM, Lange K, Moran JL, et al. (2014) Use of a concentrated enteral nutrition solution to increase calorie delivery 
to critically ill patients: a randomized, double-blind, clinical trial. Am Clin Nutr 100(2): 616-625.

18. (2012) Irish society for clinical nutrition and metabolism (adult) nutritional support giudeline.
19. (2014) Faculty of Critical Care, The College of Anesthesiologists of Sri Lanka in collaboration with Nutrition Division of Ministry of Health of Sri Lanka. Guideline on nutritional support in ICU.

Your next submission with Juniper Publishers will reach you the below assets

- Quality Editorial service

- Swift Peer Review

- Reprints availability

- E-prints Service

- Manuscript Podcast for convenient understanding

- Global attainment for your research

- Manuscript accessibility in different formats

( Pdf, E-pub, Full Text, Audio)

- Unceasing customer service

Track the below URL for one-step submission https://juniperpublishers.com/online-submission.php 